\title{
Zeoponic Plant Growth Substrate Development at the Johnson Space Center and Possible Use at a Martian Outpost
}

\author{
John E. Gruener ${ }^{1}$ and Douglas W. Ming ${ }^{2}$
}

\section{$\underline{\text { Abstract }}$}

The National Aeronautics and Space Administration (NASA) Johnson Space Center (JSC) is developing a substrate, termed zeoponics, that will slowly release all of the essential nutrients into solution for plant growth experiments in advanced life support system testbeds. This substrate is also potentially useful in the near future on the Space Shuttle and International Space Station and could eventually be used at an outpost on Mars. Chemical analyses of the martain soil by the Viking and Mars Pathfinder missions have indicated that several of the elements required for plant growth are available in the soil. It may be possible to use the martian soil as the bulk substrate for growing food crops, while using smaller amounts of zeoponic substrate as an amendment to rectify any nutrient deficiencies.

\section{Introduction}

In the first decades of the 21 st Century, it is likely that the governments of space-faring nations will work together to send human explorers to the planet Mars. These initial explorations will start small with crews of 4-8 people living in minimal outposts (NASA, 1997), but continued exploration could result in more capable facilities at a scale similar to what has developed in Antarctica. Regenerative life support systems will be required on Mars, systems that can recycle and reuse the air and water at an outpost. and can grow food for the exploration crews (Barta and Henninger, 1994). The National Aeronautics and Space Administration (NASA) is already designing and testing regenerative life support systems, including the production of food crops (Gruener et al., 1996). Techniques being developed to grow plants in advanced life support system testbeds include solution-based hydroponic systems and solid substrate-based systems.

In any plant growth system designed for use at an outpost on Mars, 16 chemical elements generally considered as essential nutrients for the growth and

1Hernandez Engineering Inc.. 17625 El Camino Real, Houston, Texas, 77058, 2NASA Johnson Space Center. Houston, Texas, 77058 
reproduction of plants must be supplied. The elements oxygen $(\mathrm{O})$, carbon $(\mathrm{C})$, hydrogen $(\mathrm{H})$, nitrogen $(\mathrm{N})$, potassium $(\mathrm{K})$, phosphorous $(\mathrm{P})$, calcium $(\mathrm{Ca})$, magnesium $(\mathrm{Mg})$, and sulfur $(\mathrm{S})$ are considered macronutrients because plants need these elements in relatively large quantities. Micronutrients, or elements that plants need in relatively small amounts, include iron $(\mathrm{Fe})$, manganese $(\mathrm{Mn})$, zinc $(\mathrm{Zn})$, copper $(\mathrm{Cu})$, molybdenum $(\mathrm{Mo})$, boron $(\mathrm{B})$, and chlorine $(\mathrm{Cl})$. While $\mathrm{O}, \mathrm{C}$, and $\mathrm{H}$ will be supplied by the air and water used throughout the outpost, the remaining 13 elements must be provided by a nutrient delivery system, which could be a hydroponic-based or solid substrate-based system.

Hydroponic, or water culture, techniques for growing plants have been used for more than 100 years by botanists and chemists, primarily to understand the fundamentals of plant physiology (Hoagland and Arnon, 1950). This is a method of growing plants with their roots in a solution containing the nutrients required for plant growth, where the solution takes the place of soil in supplying water and nutrients to the plants. Most plant growth experiments at NASA have used hydroponic systems. However. these systems involve complex plumbing networks of valves and recirculating pumps as well as sophisticated control and monitoring systems to regulate the solution ionic composition and $\mathrm{pH}$. Separate reservoirs are also required for nutrient and acid soutions. From a systems engineering and integration approach, it would be desirable to have a nutrient delivery system that: (1) has fewer parts and is easier to maintain, and (2) utilizes plumbing equipment integrated with the rest of the outpost's water delivery and management system.

\section{Zeoponic Substrate}

NASA's Johnson Space Center (JSC) is developing a solid substrate plant growth system, termed zeoponics. as an alternative to hydroponics. The goal is to develop a substrate that will deliver most of the nutrients required by plants for many growing seasons, while the remainder of the nutrients (i.e., $\mathrm{O}, \mathrm{C}$, and $\mathrm{H}$ ) are supplied by the water and air used throughout the oupost. The zeoponic plant growth system can be defined as the cultivation of plants in an artificial soil, which has the mineral zeolite as a major component (Allen and Ming, 1995). Other components in the substrate include the minerals apatite and dolomite. The zeoponic substrate has been designed to slowly release plant-growth nutrients into 'soil solution' where they become available for plant uptake, while also providing aeration, moisture retention. and mechanical support for the plants.

Zeolites are crystalline, hydrated aluminosilicates that contain exchangeable cations (e.g., $\mathrm{Ca}^{2+}, \mathrm{K}^{+}, \mathrm{Na}^{+}, \mathrm{Mg}^{2+}$ ) within their crystal structures. Zeolites have the capability to exchange some of the constituent ions freely with ions in solution without changing their structural framework. The zeolite chosen for the JSC substrate is a clinoptilolite-rich (Cp) tuff from the Fort LeClede deposit, Sweetwater County, Wyoming. The Fort LeClede clinoptilolite is nearly monomineralic with trace amounts of quartz present. as determined by X-ray diffraction analysis 
(Galindo et al., 1993). The cation exchange capacity (CEC) of the clinoptilolite is $199 \mathrm{meq} / 100 \mathrm{~g}$, determined by a $\mathrm{CsCl}$ method described by Ming and Dixon (1986). For the JSC substrate, the native clinoptilolite cations are exchanged for $\mathrm{NH}_{4}{ }^{+}$and $\mathrm{K}^{+}$cations (Allen et al. 1993), which then become the primary $\mathrm{N}$ and $\mathrm{K}$ sources for plant uptake.

The second mineral phase in the zeoponic substrate is a synthetic apatite that has been developed in laboratories at JSC (Ming and Golden, 1995; Ming et al., 1995b). Apatite is a common calcium phosphate mineral used throughout the world as a soil amendment. While natural apatite $\mathrm{Ca}_{5}\left(\mathrm{PO}_{4}\right)_{3}(\mathrm{~F}, \mathrm{Cl}, \mathrm{OH})$ is primarily used as a phosphorus source (also calcium to some extent), the synthetic apatite developed at JSC has been designed to provide the macronutrients $\mathrm{P}, \mathrm{Ca}, \mathrm{S}$ and $\mathrm{Mg}$, as well as all of the micronutrients.

Dolomite. $\mathrm{CaMg}\left(\mathrm{CO}_{3}\right)_{2}$, is the third mineral phase in the zeoponic substrate. This carbonate mineral is used as a secondary source for the macronutrients $\mathrm{Ca}$ and $\mathrm{Mg}$, and as a $\mathrm{pH}$ buffer to keep the substrate $\mathrm{pH}$ in the $6.0-7.0$ range.

Together, the zeolite, apatite and dolomite provide 13 plant essential nutrients, and when combined with $\mathrm{O}, \mathrm{C}$ and $\mathrm{H}$ from air and water constitute a complete nutrition for plant growth and development. The dynamic equilibria that take place between zeolite and apatite in a zeoponic substrate, discussed in detail by Lai and Eberl (1986) and Allen et al. (1996), is illustrated in Figure 1. In brief, Ca, $\mathrm{Mg}, \mathrm{P}, \mathrm{S}$ and micronutrients are made available to the 'soil solution' by dissolution of the apatite. Calcium and $\mathrm{Mg}$ are made available by dissolution of the dolomite. Through ion-exchange reactions, solution $\mathrm{Ca}^{2+}$ will remove $\mathrm{NH}_{4}^{+}$and $\mathrm{K}^{+}$from zeolitic exchange sites, thus making the $\mathrm{NH}_{4}{ }^{+}$and $\mathrm{K}^{+}$cations available for plant uptake. By incorporating the plant-essential nutrients into the crystalline structures of the minerals, the nutrients are less soluble in water, hence the slow-release nature of the substrate. In addition to the ions provided by the minerals, nitrifying bacteria, (nitrosomonas and nitrobacter species) are used to convert the $\mathrm{NH}_{4}{ }^{+}$ions to nitrate, $\mathrm{NO}_{3}$.

Plant growth experiments at JSC (Ming et al., 1995a) and on the Space Shuttle (Morrow et al., 1995) have successfully demonstrated the potential of zeoponic substrates. Development work and laboratory experiments continue to refine and improve the nutrient delivery capability of zeoponic substrates. 


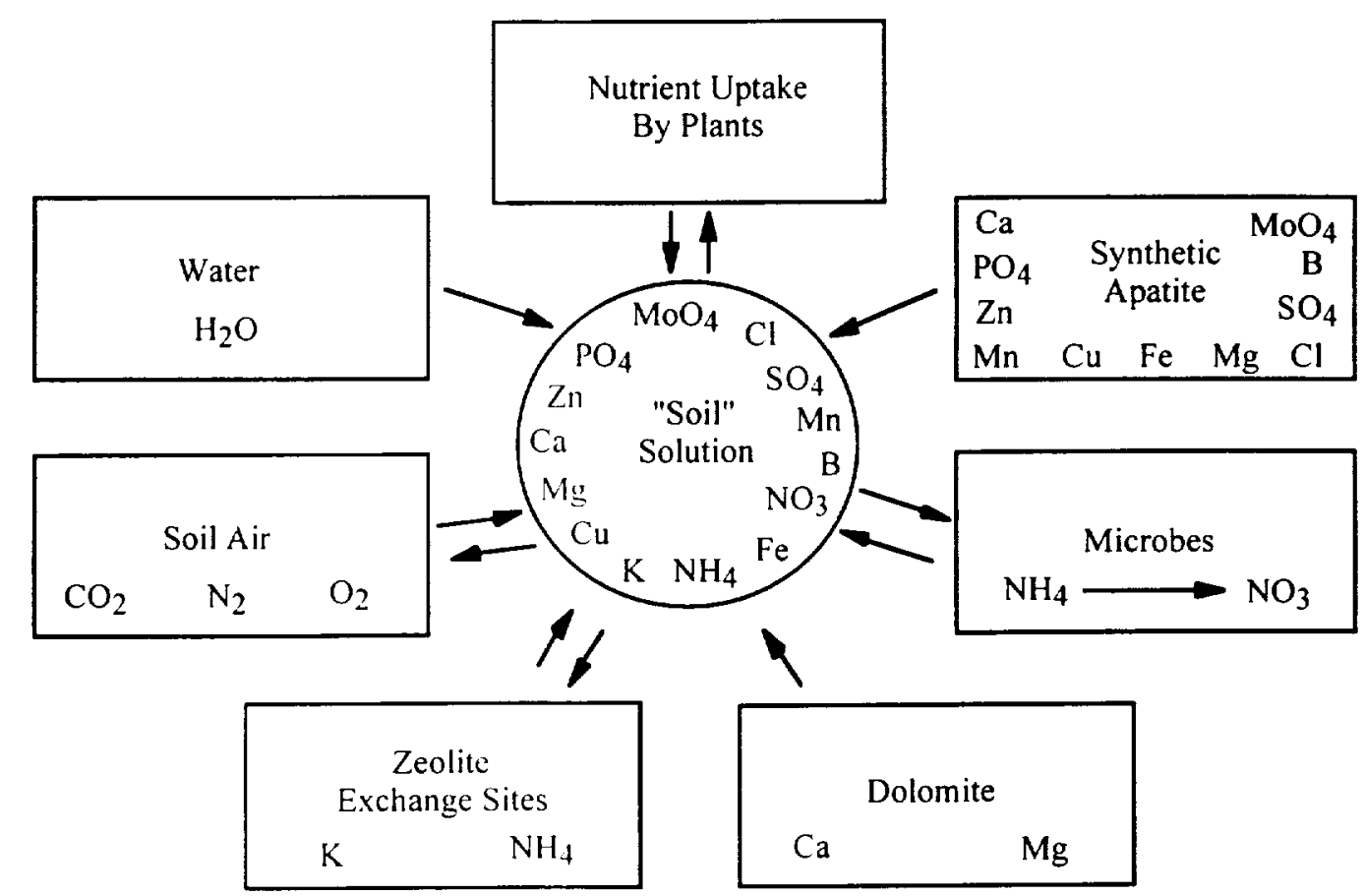

Figure 1 Dynamic equilibria for NASA's zeoponic plant growth system. The reactions in 'soil solution' (theoretically) are driven towards the root-soil interface by the uptake of nutrients by the plant.

\section{Mars Soil Chemistry}

The chemistry of the martian soil has been measured at three widely separated sites on Mars' surface. Data for the abundance of several of the plant-essential nutrients in the martian soil from the Viking 1 and 2 x-ray florescence (XRF) analyses (Clark et al., 1982), and the Pathfinder alpha proton x-ray spectrometer (APXS) analyses (Rieder et al., 1997 and Wänke et al., 1999) are summarized in Table 1. Also, shown are the elemental ranges for terrestrial soils (Lindsay, 1979) and values for a Mars soil simulant developed by JSC (Allen $e t$ al., 1998). It can be seen that the elements measured lall within the rather wide ranges of terrestrial soils, except for high concentrations of $\mathrm{S}$ and $\mathrm{Cl}$. The most plausible interpretation for the high concentrations of $\mathrm{S}$ and $\mathrm{Cl}$ in the martian soil is the formation of sulfates and chlorides by the interaction of volcanic gases with a mafic surface material (Brückner et al., 1999). The martian soil data is closely matched by the JSC Mars-1 simulant, which is made from altered volcanic ash on the Hawaiian cinder cone Pu'u Nene.

Additional chemical information on the martian soil may come out of further reduction of the Pathtinder APXS data. Data collected for $\mathrm{P}$ and $\mathrm{Mn}$ have large errors, and currently the combined abundance of $\mathrm{P}, \mathrm{Mn}$, and $\mathrm{Cr}$ is assumed to be 1.2 wt. \% (Rieder et al., 1997). Also. only data from the x-ray mode of the APXS has 
been reduced. The APXS also operated in alpha- and proton-modes. Sensitivity and resolution is excellent for the light elements $\mathrm{C}, \mathrm{N}$, and $\mathrm{O}$ in the alpha-mode (Rieder et al., 1997). Information on the micronutrients $\mathrm{Cu}, \mathrm{Zn}, \mathrm{Mo}$, and $\mathrm{B}$ is unknown at this time. It should be noted that the mineralogy of the martian soil is also largely unknown. It is important to know which minerals are present in the soil because of their differences in solubilities. Some elements, while present in the soil, may not be available to the 'soil solution' if they are bound in minerals that are not very soluble.

Table 1 Average Chemical Compositions (all values in wt. \%)

\begin{tabular}{lccccc}
\hline & $\begin{array}{c}\text { Terrestrial } \\
\text { Soils Range }^{\mathrm{a}}\end{array}$ & $\begin{array}{c}\text { Viking 1 } \\
\text { Sitc }^{\mathrm{b}}\end{array}$ & $\begin{array}{c}\text { Viking 2 } \\
\text { Site }^{\mathrm{b}}\end{array}$ & $\begin{array}{c}\text { Pathfinder } \\
\text { Site }^{\mathrm{c}}\end{array}$ & $\begin{array}{c}\text { JSC Mars-1 } \\
\text { Simulant }^{\mathrm{d}}\end{array}$ \\
\hline $\mathrm{K}$ & $0.04-3.0$ & $<0.4^{*}$ & $<0.4^{*}$ & $0.5^{* *}$ & 0.5 \\
$\mathrm{Ca}$ & $0.7-50.0$ & 4.1 & 4.0 & 4.5 & 4.4 \\
$\mathrm{Mg}$ & $0.06-0.6$ & 3.6 & $(3.6)^{\dagger}$ & 4.7 & 2.1 \\
$\mathrm{~S}$ & $0.003-1.0$ & 3.0 & 3.2 & 2.2 & $\mathrm{na}$ \\
$\mathrm{Fe}$ & $0.7-55.0$ & 12.6 & 12.2 & 12.9 & 10.9 \\
$\mathrm{Cl}$ & $0.002-0.09$ & 0.8 & 0.4 & 0.6 & na \\
\hline
\end{tabular}

${ }^{\mathrm{a}}$ Lindsay, $1979{ }^{\mathrm{b}}$ Clark et al.. $1982{ }^{\mathrm{c}}$ Rieder et al., 1997 d Allen et al., 1998

*set as upper limit by Clark ot cl.. 1982

** revised by Wänke er al., 1999

${ }^{\dagger}$ assumed same as Viking 1 site by Clark et al., 1982

na $=$ not analyzed

\section{$\underline{\text { Conclusions }}$}

Plant-essential nutrients have been shown to occur in the martian soil, and it may be possible to use martian soil as the bulk substrate for growing food crops, while using smaller amounts of a zeoponic substrate as an amendment to rectify any nutrient deficiencies in the soil. However, more research needs to be done in understanding the martian soil from an agricultural perspective. In particular, the high concentrations of $\mathrm{S}$ and $\mathrm{Cl}$ found in martian soils may lead to acidity and salinity problems.

\section{References}

Allen, C.A., K.M. Jager. R.V. Morris, D.J. Lindstrom, M.M. Lindstrom, and J.P. Lockwood (1998). JSC Mars-1: A Martian Soil Simulant. In Engineering, Construction. and Operations in Space VI, Proceedings of the Sixth International Conference on Space '98. ASCE, Reston, Virginia. pp. 469476. 
Allen, E. R., L.R. Hossner, D. II. Ming, and D.L. Henninger (1993). Solubility and cation exchange in phosphate rock and saturated clinoptilolite mixtures. Soil Sci. Soc. Amer. J.. 57. pp. 1368-1374.

Allen, E.R. and D. W. Ming (1995). Recent Progress in the Use of Natural Zeolites in Agronomy and Horliculture. In Natural Zeolites '93: Occurrence, Properties, Use. International Committee on Natural Zeolites, Brockport, New York, pp. 477-490.

Allen, E. R., L.R. Hossner. D.W. Ming, and D.L. Henninger (1996). Release Rates of Phosphorus. Ammonium, and Potassium in Clinoptilolite-Phosphate Rock Systems. Soil Sci. Soc Amer. J., 60, pp. 1467-1472.

Barta. D.J. and D.L. I Ienninger (1994). Regenerative Life Support Systems-Why Do We Need Them.' id: Space Res., 14, pp. (11)403-(11)410.

Brückner, J., G Drcibus. G. H. Lugmair, R. Rieder, H. Wänke, and T. Economou (1999). Chemical Composition of the Martian Surface as derived from Pathfinder, Viking, and Martian Meteorite Data. In Lunar and Planetary Science $X X X$, Abstract $\$ 1250$, Lunar and Planetary Institute, Houston (CD-ROM).

Clark, B.C., A.K. Baird, R.J. Weldon, D.M Tsusaki, L. Schnable, and M.P. Candelaria (1982). Chemical Composition of Martian Fines. J. Geophys. Res., 87, pp. 10059-10067.

Hoagland, D.R. and D.I. Arnon ( 1950). The Water-Culture Method for Growing Plants without Soil. Calif. Agrric. Exp. Station, Univ. of California, Berkeley, Circular 347,32 pp.

Galindo, C., Jr., D.W. Ming. E.R. Allen, D.L. Henninger, and L.R. Hossner (1993). Characterization of starting materials in zeoponic plant growth systems. In Zeolites '91: Memoirs of the 3rd Int. Conf. on the Occurrence, Properties, and Utilization of Narural Zeolite, Part II, Havana, 1991., International Conference Center, Ilisana, Cuba, pp. 8-13.

Gruener, J.E., D.W. Ming, D.J. Barta, and D.L. Henninger (1996). Plant Growth Experiments in Johnson Space Center's Advanced Life Support System Program. In Engineering, Construction, and Operations in Space $V$, Proceedings of the Fifth International Conference on Space '96. ASCE, New York. pp. 1090-1094.

Lai, T. M. and D.D. Eberl (1986). Controlled and renewable release of phosphorus in soils from mixtures of phosphate rock and ammonium-exchanged clinoptilolites. Zeolites. 6. pp.129-132. 
Lindsay, W.L. (1979). (hemical Equilibria in Soils. John Wiley and Sons, New York.

Ming, D. W. and J.B. Dixon (1986). Clinoptilolite in South Texas Soils: Soil Sci. Soc. Am. J., 50. pp. 1618-1622.

Ming, D.W., D.C. Golden, and D.L. Henninger (1993). Utilization of On-Site Resources for Regenerative Life Support Systems at Lunar nad Martian Outposts. SAE Technical Paper 932091, SAE, Warrendale, Pennsylvania, 11 pp.

Ming, D.W., D.J. Barta. D.C. Gulden, C. Galindo, Jr., and D.L. Henninger (1995a). Zeoponic Plant-Growth Substrates for Space Applications. In Natural Zeolites '93: (ccurrence. Properties, Use. International Committee on Natural Zeolites. Brockport, New York pp. 505-514.

Ming, D.W., D.L. Henninger, E.R. Allen, and D.C. Golden (1995b). Active Synthetic Soil. U.S. Patent \# 5,451,766. Date of Patent September 19, 1995.

Ming, D.W., and D.C. Golden (1995). Slow release fertilizer. U.S. Patent \# 5,433,766. Date of Patent July 18, 1995.

Morrow, R. C., N.A. Duffie, T.W. Tibbitts, R.J. Bula, D.J. Barta, D.W. Ming, R.M. Wheeler, and D.M. Portertield (1995). Plant Response in the ASTROCULTURE Flight Experiment Unit. SAE Technical Paper 951624, SAE, Warrendale, Pennsylvania, $7 \mathrm{pp}$.

NASA (1997). Human Exploration of Mars: The Reference Mission of the NASA Mars Exploration Study Team. NASA SP-6107.

Rieder, R., T. Economou. H. Wänke, A. Turkevich, J. Crisp, J. Brückner, G. Dreibus, and H.Y. McSween Jr. (1997). The Chemical Composition of Martian Soil and Rocks Retuned by the Mobile Alpha Proton X-ray Spectrometer: Preliminary Results from the X-ray Mode. Science, 278, pp. $1771-1774$.

Wänke, H., J. Brückner, G. Dreibus, G.W. Lugmair, R. Rieder, and T. Economou (1999). The Chemical Composition of the Martian Surface. In The Fifth International Conference on Mars, Abstract \#6046. LPI Contribution No. 972, Lunar and Planetary Institute, Houston (CR-ROM). 